\title{
Imperial or Settler Imperative? Indigenous Reserves as a Case Study for a Transcolonial Analysis of British Imperial Indigenous Policy
}

\author{
Darren Reid* \\ University of Victoria \\ Dreid820@yahoo.ca
}

\begin{abstract}
My paper presents a comparative analysis of the development of reserve systems in British North America and Western Australia across the 19th century. The existing historiography seeks to comprehend the relationship between the British metropole and the colonial periphery, and two opposing frameworks of colonial governance have been developed. One holds that the British Empire operated as an interdependent system, in which colonial Indigenous policies were determined by overarching imperial imperatives based upon imperial capitalism and liberal humanitarianism. The other holds that the explosive growth of settler communities undermined these imperial imperatives and facilitated governance guided by the settlers' need for land, labour, and security. This paper seeks to end the tension between these two frameworks by using Indigenous reserve systems as a case study for understanding colonial governance. Through an analysis of correspondence between local and imperial administrators, this paper argues that the development of Indigenous reserve systems reveals an entrenched conflict between imperial and local administrators lasting throughout the nineteenth century, a conflict in which the local governments of British North America and Western Australia subordinated imperial imperatives of imperial capitalism and liberal humanitarianism to local concerns of security and sovereignty.

Keywords: Settler colonialism; transcolonial history; British policy; Indigenous reserves
\end{abstract}

$\mathrm{T}$ he national histories of Western British North America (Western BNA) and Western Australia give ample attention to the Indigenous reserve systems of each country, but little attention is given to transcolonial patterns of dispossession. Transcolonial history is a unique approach to the history of colonial governance, which problematizes the idea that historians can understand the course of settler-Indigenous relations in any one country from within national boundaries. Zoe Laidlaw, historian at the University of London, expounds the need to re-examine colonial governance from an international viewpoint. Laidlaw argues that the contained national histories of colonization prevent historians from making important connections between colonized peoples, enable modern settler societies to perpetuate dispossession, and allow Britain to side-step questions of responsibility for imperial crime (2014, p. 133).

Transcolonial historical analyses acknowledge that national acts of colonialism, such as the creation of Indigenous reserves, are individual instances of a larger phenomenon, and dig deeper into the differences between these to better understand the whole.

Historians tend to consider British Indigenous policy as driven by a dialectic between, on the one hand, a framework of imperial liberal humanitarianism and imperial capitalism and, on the

*I would like to thank Dr. Elizabeth Vibert for her guidance while writing this paper. 
other hand, a framework of settler colonialism 11 Yet the reserve systems that coalesced in British colonies by the end of the 19th century contained aspects that contradicted the principles of both frameworks. As a response to Laidlaw's call for transcolonial approaches to colonial governance, this paper seeks to reconcile these two frameworks via a transcolonial comparison of Indigenous reserve policy. I argue that, while imperial imperatives guided the development of early 19th century reserves, the coercive forms of reserves that appeared by the turn of the century arose only as settler populations came to prioritize the security of their land and the solidity of their claims to sovereignty over imperial obligations.

This paper has three sections. The first section is an exploration of the historiography of world patterns of Indigenous-settler relations. The second section presents my own primary research into the processes of developing reserves in Western $\mathrm{BNA}^{2}$ and Western Australia, organized geographically. By Western BNA, I refer to present day Alberta, Saskatchewan, and Manitoba. In the name of feasibility and length, I focused on two nations for the similarity of their contexts: Both represent frontiers that were settled after the initial settlement of their corresponding colonies. The third section connects the findings from my research along world patterns, organized thematically. Finally, there are brief concluding remarks.

\section{Terms}

I use the term "Indigenous" rather than "native" or "aboriginal" to refer to Indigenous peoples and groups; while it is preferable to refer to the self-designated appellations of any Indigenous group, in the context of this paper the purpose is not to refer to specific Indigenous histories but to policies and colonial reactions to Indigeneity as a concept. Historical documents of this time refer to Indigenous groups as "natives," and while I keep this term where necessary, bear in mind the legacy of racist attitudes towards "the noble savage" that is attached to this term. I would also draw attention to the term "Indigenous policy." The term conjures an image of "what the government did with Indigenous people," but this is untrue. Policy indicates government intentions, but the Indigenous groups involved responded to these intentions in many ways and influenced the outcomes of policy. I will draw attention to divergences between policy intentions and Indigenous responses when necessary.

The dichotomy of imperial and local also requires a brief note. "Imperial" and "local" are not directly antonymous, as the appointed governor of a colony could be just as imperially-minded as any official back in London. To control for the ambiguity in separating imperial imperatives from local imperatives, I define local imperatives against the imperatives established by the British Colonial Office. For example, if a dispatch from the Secretary of State for War and the Colonies outlines a specific instruction regarding Indigenous policy, then I take that policy as the established imperial policy. Likewise, if a dispatch from a colonial governor presents an Indigenous policy that is divergent from the established imperial policy, then I take the divergent policy as the established local policy ${ }^{3}$

\footnotetext{
${ }^{1}$ I refer to settler colonialism as defined by Adam Barker and Emma Battell Lowman: "Settler colonialism can be distinguished from other forms of colonialism-including classical or metropole colonialism, and neo-colonialism-by a number of key features. First, settler colonisers 'come to stay': unlike colonial agents such as traders, soldiers, or governors, settler collectives intend to permanently occupy and assert sovereignty over Indigenous lands. Second, settler colonial invasion is a structure, not an event: settler colonialism persists in the ongoing elimination of Indigenous populations, and the assertion of state sovereignty and juridical control over their lands" (Barker \& Battell Lowman [2015], "Settler Colonialism," para. 1).

${ }^{2}$ Arriving at a succinct name for this area is difficult, given that "Central Canada" is anachronistic and "Prairie British North America" is awkward. "Central British North America" would also have worked.

${ }^{3}$ Strictly speaking, there was no such thing as one coherent British imperial policy, since imperial policy was determined by a range of contradictory intentions and desires. However, for the purpose of this paper the documented
} 
Finally, given that reserves have existed for centuries while the subject of this paper is a very specific type of reserve from the 19th century, I propose three distinct terms that should be helpful: unprescribed reserves, prescribed reserves, and institutionalized reserves. Unprescribed reserves are simply lands that had been set aside by colonial authorities for use by Indigenous peoples with no immediate intention to assert authority over them. Consider the Royal Proclamation of 1763, which reserved land as hunting ground and not for coercive purposes (Miller, 2009, p. 69). Prescribed reserves are those that have been set aside for Indigenous peoples' use with accompanying caveats, such as agreements to build houses or learn agriculture. For example, consider the reserves created by Sir Francis Bond Head in the Manitoulin Treaty (1836), which stipulated that the Indigenous people might live traditionally, "inasmuch as it affords fishing, hunting, bird-shooting, and fruit" (Bond Head, 1839/1969, p. 350) or request assistance "to become civilized and to cultivate land" (Bond Head, 1839/1969, p. 352). Institutionalized reserves are those in which Indigenous people must have lived and where the lives of Indigenous people were coercively controlled. This paper focuses on two specific versions of institutionalized reserves: those in Western BNA after the rise of the 1885 pass system and those in Western Australia created by the 1905 Aborigines Act.

\section{Imperial- and Local- driven Frameworks of Colonialism}

\section{Imperial-driven frameworks}

Transcolonial historians have developed two distinct frameworks of British Indigenous policy, each opposing the other. The first direction works under the assumption that the British Empire operated in a systemic fashion. Oxford historian John Darwin asserts a framework of empire in which Britain created an "octopus shaped" world system with systemic control from the centre (2009, pp. 17-18). Darwin's argument assumes that the colonies acted as auxiliaries to a metropolitan center, with the needs of the metropole determining the governance of the auxiliaries. Darwin's systemic empire framework holds that the governance of the British colonies was principally guided by imperial capitalism and therefore implies that the metropole designed local governments' Indigenous policies to facilitate Britain's capitalist agendas $4^{4}$

Similar work on liberal humanitarianism supports the framework of an overarching, systemic ideology driving colonial governance. Andrew Armitage, professor of social policy, connects the British assimilationist goal to the 1834 British Poor Law 5 in that both policies approached nonmainstream groups like indigent Britons and Indigenous peoples as requiring government programs to assimilate them into mainstream society (1995, p. 4). According to Armitage, since the 1834 Poor Law was a fundamental aspect of liberal humanitarianism, the similarities between assimilation policies and poor law policies indicate that liberal humanitarianism spread from the British metropole outwards to the colonies and that liberal humanitarianism was therefore a systemic ideological influence on colonial Indigenous policy.

\footnotetext{
policy (i.e., whatever was written down in an official dispatch) will be taken as the dominant imperial policy

${ }^{4}$ It is important to note here a distinction between imperial capitalism and colonial or local capitalism. Imperial capitalism operates to benefit the metropole, just as Darwin argues that the colonies worked to serve imperial interests. Colonial or local capitalism operates to benefit the setters of the colony. This means that imperial and local capitalism are not necessarily antagonistic, as a thriving local economy may very well benefit the metropole, but it does require differentiation. This is my own definition.

${ }^{5}$ The idea of the 1834 Poor Law was to prevent impoverished individuals from becoming a burden on the state by forcing them to labour in workhouses in return for any social assistance, as well as to reclaim indigent children from the perceived immorality of their parents by providing limited industrial education.
} 


\section{Local-driven frameworks}

The second direction that transcolonial history has gone works under the assumption that either there never was any systemic control of policy in the British Empire or at least that the systemic control had disappeared by the late 19th century. Oxford historian James Belich argues that Indigenous groups across the British Empire were initially capable of resisting the advances of imperial capitalism, and therefore imperial capitalism cannot have dictated Indigenous policies (2009, p. 225). Their ability to resist deteriorated in the second half of the 19th century in the face of massively increasing numbers of settler emigrants from Britain, an event he terms "explosive colonization." Belich argues that at the centre of explosive colonization was the "boom mentality" of emigrant settlers, in which British settlers placed the security of frontier borders (i.e., non-confrontational relations with Indigenous groups) above their concern for economic or moral objectives. This argument undermines the framework of an overarching imperial imperative driving colonial governance, as these imperatives place economic and moral objectives above concerns of safety and stability (Belich, 2009, pp. 225-227).

\section{Reserves as Contradictory to the Transcolonial Historiography}

These two frameworks of British transcolonial history, that of an overarching capitalist or liberal humanitarian imperative and that of a local imperative, require us to take a closer look at the purposes of Indigenous reserves across the British Empire because neither framework can sufficiently explain the institutionalized reserves of the late 19th century. Both imperatives demand the inclusion of Indigenous peoples within the British system, yet the purpose of institutionalized reserves is to isolate them from it.

Armitage argues that the general policy of isolating Indigenous people upon reserves and forcing them to abide by British law and morality was adopted on an imperial scale by the 1837 Report of the Select Committee on Aborigines, and that local governments followed this imperial policy throughout the colonies for over a century afterwards (1995, p. 220). However, a careful reading of the Report shows that imperial authorities believed inclusion into British society furthered the "civilizing" 6 of Indigenous people, and that isolation hampered it. The Committee declared that "the relations between neighboring nations must ever be extensive, however great the disparity of intellect or cultivation; and it is very questionable, whether it would be proper to restrain this relationship, when it might be conducted in an enlightening manner" (British Parliamentary Select Committee, 1837/1966, p. 152). Furthermore, the Report stated that British laws do not apply to Indigenous groups, "the whole spirit and principles of which are foreign to their modes of thought and action" (British Parliamentary Select Committee, 1837/1966, p. 80). One may argue that the Select Committee intended these stipulations to be temporary measures, and Armitage points to signs that indicate the intention of imperial authorities to scale back these protections in time. Yet if we took these indications for granted, we would be reading history backwards. The isolationism and forced legal and moral policing of the institutionalized reserves that local governments established by the end of the 19th century, and which Armitage links to the Report of the Select Committee of 1837, contradicted the imperial directive set down in writing, and so the theory that an overarching metropolitan imperative drove Indigenous policy falls short.

\footnotetext{
${ }^{6}$ I use the terms "civilize" and "civilizing" throughout this paper to refer to the liberal humanitarian "civilizing mission." The idea of levels of civilization was rooted in Eurocentric Enlightenment ideas of progress and was popularized by the Marquis de Condorcet's "Progress of the Human Mind," which categorized ten epochs of civilization, such as formation of hordes, adoption of pastoralism, adoption of agriculture, division of the sciences, decline of science and rise of theology, etc. I refer to this highly unscientific and racist idea as historical context, not as historical fact.
} 
However, the concept of settler needs for peaceful and secure borders driving Indigenous policy also cannot explain the development of institutionalized reserves because an inherent characteristic of reserves across the empire was the intent to raise the "level of civilization" of Indigenous peoples, something that was expensive and not required for the needs of boom mentality. Amanda Nettelbeck, historian at the University of Adelaide, argues that the policy of providing rations was an integral aspect of Indigenous policy and necessary for the survival of Indigenous groups, but was only supported by colonial governments when unavoidable out of the fear that rations would lead to idleness (Nettelbeck \& Foster, 2012, pp. 24-26). Reserve overseers in Western Australia explicitly refused to provide rations to "indigent blacks on stations where able-bodied ones are employed" (Western Australia Aborigines Department, 1905, p. 6), and reserves in Western BNA adopted the strategy of providing rations only in payment for jobs around the reserves (Satzewich, 1996, pp. 199-200). This preoccupation with enforcing moral norms on the residents of reserves, which was almost unanimously resisted, is irreconcilable with the settler' need for reducing confrontation and maintaining peaceful borders. Much of the motivation for these polices included financial concerns, but the civilizing concern was emphasized. And so, the theory of boom mentality driving Indigenous policy also falls short.

This paper analyzes the similarities and divergences within the processes of creating reserve systems in Western BNA and Western Australia and proposes a revised framework for understanding British colonization in which reserve systems are not anomalous. This section has outlined the two most dominant frameworks already developed and highlighted their weaknesses in regards to reserves. The next section looks at the contexts of reserves in each colony, weighs the debates between local and imperial administrators, and scrutinizes government reports to distill the essential purposes and functions of institutionalized reserves in each colony.

\section{Tracing the Development of Institutionalized Reserve Systems}

\section{Western British North America}

Armitage's view of BNA Indigenous policy corresponds with the current historical consensus. Canadian historian Jim Miller argues that the BNA government adopted a "civilizing" policy at the end of the War of 1812, when the state grew less dependant on Indigenous military aid, and that this policy became increasingly assimilationist over the decades as settlers came to see Indigenous groups as inhibitory to progress (Miller, 2009, p. 105). Just as Armitage sees BNA Indigenous policy as established once and maintained for a century, Miller argues for one progressively assimilationist civilizing policy. I offer a new framework of 19th century Western BNA Indigenous policy as an ongoing debate between two iterations of civilizing policy: active civilizing via social integration and social isolation without civilizing. I argue that a civilizing policy was adopted after the War of 1812, but that this policy was replaced by one of isolationism and control which had nothing to do with a civilizing mission and everything to do with security.

This framework accounts for the institutionalization of reserves in 1885, while the previous assumption of one assimilationist policy fails to explain this isolationism. The Canadian government established the pass system in 1885, which required Indigenous individuals to obtain passes to leave their reserve and effectively institutionalized the reserves 7 The creation of the pass system in 1885 was linked with the 1885 North-West Uprising and had roots in the Manitoulin Treaties of 1836.

\footnotetext{
${ }^{7}$ There is a debate among historians as to the pass system's enforcement: No legislative backing was introduced for the pass system, and so police made arrests based on drunkenness and vagrancy rather than pass violation. However, oral histories support its operation into the 1930s. See Carter and Hildebrandt, The True Spirit and Original Intent of Treaty 7. However, Indigenous people did not leave the system unchallenged and repeatedly and often left the reserve without obtaining a pass. See Barron, "The Indian Pass System in the Canadian West, 1882-1935."
} 
Sir Francis Bond Head, Lt. Governor of Upper Canada, signed the Manitoulin Treaties with the assertion that "[t]he greatest kindness we can perform towards these intelligent, simple-minded people, is to remove and fortify them as much as possible from all communication with the whites" (Bond Head, 1839/1969, p. 353). The Manitoulin Treaties are as noteworthy for what they did not include as for what they did include: They did not include any promises to provide religious instruction or education of any kind, but rather encouraged traditional Indigenous methods of subsistence via hunting, fishing, gathering, and bird-shooting (Bond Head, 1839/1969, p. 350). This policy of social isolation without civilizing was a direct departure from the imperial Indigenous policy established in 1830, when the then-governor Sir James Kempt declared that "[t]he rooted aversion entertained by the Indians to intermix with the white population, and with other Indian tribes, renders it necessary that they should be located ... in the vicinity of other tribes and of white settlers. By these means ... their amalgamation with the mass of the population [will] be most efficiently promoted" (Kempt, 1834/1969, p. 95). Furthermore, Kempt had been ordered by the Secretary of War and the Colonies, Sir George Murray, to ensure the encouragement "in every possible manner, of religious knowledge and of education generally" (Murray, 1834/1969, p. 88). Bond Head's repudiation of Kempt's and Murray's policy of integration and education indicates that there was a debate, from the earliest years of policy making, between proponents of active civilizing via social integration and social isolation without civilizing.

Bond Head's iteration of civilizing policy was not popular with the imperial government. Indigenous leaders themselves petitioned the imperial government, with Mississauga leader Peter Jones travelling to London to personally denounce Bond Head's policy (Binnema \& Hutchings, 2005, p. 130). Secretary of War and the Colonies Lord Glenelg rejected the policy in 1838 and declared that "[t]he view which Sir F. Head adopted of the future prospects of the Indian race differed no less from the opinion of his predecessors in the government of Upper Canada than from those which I had been led to form" (Glenelg, 1839/1969, p. 314). Consequently, the signing of the first seven numbered treaties in the North-West Territories between 1870 and 1877 followed Kempt's iteration of active civilizing via social inclusion. During the negotiation of Treaty No.1 (at the site of modern-day Winnipeg, Manitoba, in August 1871), Indian Commissioner Wemyss Simpson perceived "with much pleasure" that "the Indians have evinced a most friendly disposition, and look upon the emigrants and others now passing through their country, not only without distrust, but with evident satisfaction, and we have no doubt but that, by careful and prudent management, these friendly relations may be permanently maintained" (Indian Branch of the Department of the Secretary of State for the Provinces, 1871, p. 9). This indicates that the intention of the treaty was not to restrict relations between Indigenous people and settlers, but to ameliorate them. Indeed, Simpson's Indian Department Annual Report of 1871 satisfactorily reported that

In the province of Manitoba, where labours [sic] is scarce, Indians give great assistance in gathering in the crops. At Portage La Prairie, both Chippewas and Sioux, were largely employed in the grain field, and in other parishes, I found many farmers whose employees were nearly all Indians .... Although serious trouble has from time to time occurred ... there is no reason to fear any trouble with those who regarded themselves as subjects of her majesty. Their desire is to live at peace with the white man, to trade with him, and, when they are disposed, to work for him. I believe that nothing but gross injustice or oppression will induce them either to forget the allegiance which they now claim with pride, or molest the white subjects. (Indian Branch of the Department of the Secretary of State for the Provinces, 1871, p. 31)

The satisfaction with settlers employing and trading with Indigenous people shows that the Indigenous 
policy behind the numbered treaties followed Kempt's policy of active civilizing via social integration 8

This changed in 1885, when the Canadian government's belief that "nothing but gross injustice or oppression will induce them either to forget the allegiance which they now claim with pride, or molest the white subjects" (Indian Branch, 1871, p. 31) was shattered by the North-West Uprising. Several Indigenous nations rose against the Canadian government in 1885 in response to settler encroachment, and the government abandoned Kempt's style of inclusionary policy to prevent future uprisings. While modern historians acknowledge that the uprising was a justified course of action taken after many attempts at peaceful negotiation, the government at the time saw no justifiable motivation for Indigenous groups to resort to violence. In his annual report for 1885, Sir John A. Macdonald established that the uprising was "due to circumstances over which this Department had no control, but which were the result of specious inducements held out to Indians of the North-West Territories by the leader of the half-breed insurgents and his lieutenants" (Canadian Department of Indian Affairs, 1886, p. 7). Since there was no official perception of the uprising being the result of any real grievances, the government's only means of preventing further violence was to address what they did perceive to be the cause of the uprising: communication between Indigenous groups and outsiders. Consequently, they designed the pass system to control communication. Canadian historian Sarah Carter doubts the Indian Department's belief that the Indigenous participants in the 1885 uprising had no actual grievances with the government, and she points to evidence of hushed-up criticisms of the government's poor management of reserves (1990, pp. 130-34). While this perspective is important to think about, my purpose in writing is to trace and compare Indigenous policies, and determining if officials believed in their policies is beyond the scope and purpose of this paper.

Officials first mentioned forcing Indigenous people onto their reserves in May 1885, during the North-West Uprising, when Major-General Middleton wrote to Lieutenant Governor Dewdney asking, "[w]ould it not be advisable to issue a proclamation warning half-breeds and Indians to return to their Reserves and that all those found away will be treated as rebels?" (Middleton, 1885/2009, p. 63). Dewdney made this proclamation immediately, and three months after the end of hostilities, Deputy Superintendent General of Indian Affairs Lawrence Vankoughnet argued that not just the hostiles, "but all our Indians should be required to carry passes," and Prime Minister Macdonald agreed that "the system should be introduced in the Loyal Bands as well" (Vankoughnet, 1885/2009, p. 64).

The second motivation for expanding the pass system was the perception that the Indigenous population's food supplies were being compromised by farmers abandoning their crops. The Annual Report of 1886 explains that

So for many of them ... having in the excitement of the occasion [the North-West Uprising] left their reserve, no seed was planted .... As in the case of other bands on reserves, situated in the districts affected by the disturbances referred to, these Indians had for the most part to be entirely fed at the expense of the government. [Furthermore,] the ease with which employment is obtained and money earned in summer renders many Indians careless and neglectful of their crops. (Canadian Department of Indian Affairs, 1887, p. 81)

Carter disputes the government's position that poor agricultural production was a result of Indigenous carelessness and neglect, instead pointing to a multitude of other handicaps, such as poor soil conditions, an inability to relocate to better soil, and rampant equipment shortages (1990, pp. 161-63). However, this report illustrates that the pass system was a measure to ensure sufficient

\footnotetext{
${ }^{8}$ It should be noted that Indigenous people chose to work for white farmers as a response to food scarcity, not because integration was the policy. Policy agreed with Indigenous action rather than caused Indigenous action.
} 
agricultural productivity upon reserves, since the government thought agricultural production was being hindered by Indigenous farmers leaving their reserves ${ }^{9}$

Rather than there being one century-long assimilation policy, the adoption of the pass system represents the abandonment of the policy of active civilizing via social integration and the reversion to a policy similar to Bond Head's previous policy of social isolation without civilizing. The pass system had different reasons for isolating Indigenous peoples than Bond Head's Manitoulin Treaties, replacing his 1836 despair over the Indigenous population's ability to become civilized with the 1885 fear of warmongering and inciteful communication between Indigenous groups and the determination to have Indigenous groups produce enough food for themselves. Nonetheless, it is necessary to appreciate that the institutionalization of reserves in Canada was reversion to an isolationist, non-civilizing policy rather than the failure of a civilizing policy.

\section{Western Australia}

The institutionalization of reserves in Western Australia developed as a combination of two intersecting forces: settlers' desire to harness the Indigenous population as a source of cheap labour and the increasing settler fear of Indigenous people as decimation of kangaroo herds led them to cattle raiding 10

The Australian government neither hid nor denied its obsession with utilizing the labour potential of Indigenous peoples, for Western Australia directly refuted the imperial government's desire for a civilizing-focused Indigenous policy by adopting a labour-focused Indigenous policy. Following the 1837 Report from the Select Committee on Aborigines (British Settlements), Secretary of State for War and the Colonies Lord Glenelg sent a dispatch to George Gipps, the governor of New South Wales, dated 31 January 1838. This dispatch outlined the Indigenous policy that Australia was to adopt, which involved creating an office of "Protectors of Aborigines" and instructing these protectors that "if the natives can be induced in any considerable numbers to locate themselves in a particular place, it will be the object of the protector to teach and encourage them in the cultivation of their grounds" (Glenelg, 1839/1970, p. 375). However, when John Hutt, the governor of Western Australia, received these instructions, he ignored them. Instead, he created an office of protectors for which he "considered that the object of the appointment of protectors is, that they may guard against and inquire into any cause of complaint which may arise between the white people and the aborigines" (Hutt, 1844/1969, p. 371). This was a very different policy from what Glenelg had outlined, and Hutt acknowledged this in a dispatch dated 15 May 1841, in which he offered several remarks "explanatory of the reasons which have prevailed with me not to adopt, for the present at least, the suggestions contained in these papers, but rather to afford complete trial to the system in force in this colony" (Hutt, 1844/1969, p. 380). His predominant argument was that if Indigenous people of New South Wales were hostile to settlers and needed to be held on reserves, the Indigenous people of Western Australia were entirely friendly. These dispatches illustrate both that Western Australian Indigenous policy from the very beginning centered on promoting Indigenous people's employment by settlers and that the Western Australian colonial government rejected the imperial desire to institute a system of reserves.

Unlike the above exploration of Western BNA, in which reserve policy evolved according to the government's changing perceptions of Indigenous groups, the Western Australian perception never changed: It was always about labour. Instead, institutionalized reserves developed supplemental to the policy of harnessing cheap labour as a structure to take advantage of the Indigenous population's

\footnotetext{
${ }^{9}$ Not only was the government determined to prevent Indigenous people from rising up out of hunger, but they also wanted to limit the expense of providing rations.

${ }^{10}$ The decimation of buffalo herds in BNA also highly impacted Indigenous people's ways of life, but there was not a parallel fear of cattle raids reflected in government correspondence.
} 
declining access to traditional kangaroo herds. Governor Hutt's policy expressed the opposite of Lord Glenelg's imperial policy of reforming hunter-gatherers into farmers. Hunter-gatherers were to work on settler farms, but they were never meant to start farming for themselves, for there was a strategic use for government rations as motivation to work for settler farmers. By the 1840s, Western Australia had a defined policy of using the provision and refusal of food rations to attempt to control Indigenous actions. In his annual report of 1840, Protector of Aborigines Charles Symmons explained that

To endeavor to wean the natives from their habits of indolence, and determined system of begging, I have invariably refused money or food without having previously obtained some equivalent service.... To evince our disgust at outrages which, however revolting to civilization, have been perpetrated by the natives .... I have invariably punished the offenders by banishment from the town, for a limited period, thus depriving them of many of their comforts, and compelling them to seek a precarious subsistence in the chase. (Symmons, 1841, p. 3)

The carrot and stick were, respectively, government rations and forced dependence on hunting and gathering, though it is important to note that employers, rather than officials, distributed government rations. There was a fear, in accordance with the predominant Western understanding of the relationship between poverty and poor relief, that giving out rations freely would demotivate Indigenous people from working, and so, as Symmons mentioned above, employers would only give rations in exchange for work.

Unfortunately for the settlers, this policy backfired because of the encroachment of European settlement on the ability of Indigenous groups to hunt for subsistence. As settlement grew, the destruction of kangaroo habitat in addition to the overhunting of kangaroo, which was a traditional source of food among the Western Australian Indigenous population, resulted in a growing desperation for food. Ideally (for Governor Hutt), this would have led to a heightened effectiveness of rations in forcing obedience, but the destruction of kangaroo herds resulted in an increase in cattle theft. As early as 1842, settler pastoralists were making the connection between settler encroachment and the steadily increasing Indigenous criminality. John Hunter Patterson, a pastoralist voicing his opinion in the Australasian Chronicle, argued that

It now appears to be established beyond the reach of dispute that the extensive occupation of the territory has produced a scarcity of those plants and animals which constituted the staple articles of their subsistence; and this view is confirmed by the fact, that the depredations of the aborigines have been, hitherto committed with the sole purpose of obtaining food or clothing. In these circumstances it is sufficiently obvious that, before any system can be devised for ameliorating their condition, an adequate provision must be made for supplying them with the first necessaries of life, for it is idle to talk of reforming, or even of restraining, by punishment or otherwise, a starving population. (Patterson, 1842, p. 4)

This situation forced an alteration to the practice of using rations as incentive, as public fear of and outcry against the rising Indigenous criminality necessitated that distributors provide rations to those Indigenous people who were fit neither to hunt nor to work, in order to address the root cause of cattle theft. It was found that sick, young, and elderly relatives of Indigenous labourers required more food than a labourer could obtain legally, and so in 1878, the government established a daily ration for non-labourers. In accordance with the earlier policy, employers and farmers (rather than officials) would give out these rations (Nettelbeck \& Foster, 2012, p. 29). This change in rations policy illustrates the agency of Indigenous workers within a highly restrictive situation, as 
officials were forced to compromise their concerns over idleness and morality as a result of Indigenous choices to support their family members rather than blindly obey foreign codes of behaviour that the government sought to force upon them.

While delegating the distribution of rations to the employers had the bonus of incentivising Indigenous people to work as labourers, it also made them more vulnerable to settler exploitation. Awareness of, and advocacy against, the exploitation of Western Australian Indigenous people became a highly visible and contentious issue during the 1880s, when Reverend John Gribble, Lieutenant Colonel E.F. Angelo, and Magistrate R. Fairbairn released scathing indictments of the "disguised but unquestionable system of slavery carried on under the protection of the British flag" (Churches, 2006, p. 3). These allegations resulted in the appointment of the Royal Commission on the Condition of the Natives in 1904, upon whose recommendations the government passed the 1905 Aboriginals Act and 1905 Native Administration Act. The commission discovered that

The same people who distribute rations, charged to the Government, for the relief of indigent and other aborigines, benefit themselves by buying at wholesale and charging at retail current prices, issuing about half the allowance, distributing the food cooked instead of raw. (Royal Commission on the Condition of the Natives, 1905, p. 22)

To combat this abuse, the commission recommended that "the indigent blacks should, as far as practicable, be collected on to a reserve," and that "the distributors of relief should be responsible persons, preferably Government officials" (Royal Commission on the Condition of the Natives, 1905, p. 24). In his 1905 Annual Report, Chief Protector of Aborigines Henry Prinsep agreed with these recommendations, but lamented that, regarding the collection of Indigenous people upon reserves, "I have tried this over and over again, but under the present law I cannot keep them there. They will have their own way and wander where they like" (Western Australia Aborigines Department, 1905, p. 6). Consequently, the passage of the 1905 Aboriginal Act included article 12:

The Minister may cause any aboriginal to be removed to and kept within the boundaries of a reserve, or to be removed from one reserve or district to another reserve or district, and kept therein. Any aboriginal who shall refuse to be so removed to or kept within such reserve or district shall be guilty of an offence against this Act. (Western Australia Houses of Parliament, 1905, p. 4)

The complete reversal of policy from Governor Hutt's refusal to create reserves to Chief Protector Prinsep's lobbying for reserves was therefore a reaction to the starvation caused by settler encroachment on Indigenous hunting grounds. There was some minimal humanitarian motivation in terms of anti-exploitation advocacy, but the prominent motivation for the confinement of the Indigenous population to reserves was the desire to manufacture a dependence upon government-distributed rations as an inducement into employment, as well as the fear of hostility via cattle theft. Unlike Western BNA, where Indigenous policy changed in relation to the perceived vision of the place of Indigenous people in settler society, Western Australian Indigenous policy never strayed from its focus on settler need for labour, and instead changed in relation to practical and logistical circumstance.

\section{Transcolonial Themes: Imperial-Local Conflict and Definitions of Civilize}

The reserve systems that developed in Western BNA and Western Australia shared many similarities, enough to suggest that they adhered to the model of British systemic imperialism. Yet these reserves also exhibited substantial differences, which would suggest that they adhered to 
the model government driven by local imperatives. This section compares the processes of reserve development to move towards a resolution of this contradiction. A comparative analysis reveals two primary themes that connect the reserve systems in each country: conflict between imperial and local administrators in the purpose and implementation of reserves and investment in the idea of a civilizing mission.

\section{Imperial Colonial Conflict}

In Western BNA and Western Australia, Indigenous policies vacillated between different points on a spectrum of desired Indigenous integration into settler society ${ }^{11}$ In Western BNA, Bond Head's Manitoulin Treaties of 1836 asserted a novel definition of reserves - as places to separate Indigenous peoples from settler society - that was forcefully reversed by Lord Glenelg in 1838. This antagonism is paralleled in Western Australia by the conflict between Governor Hutt's vision of Indigenous people as labourers and Lord Glenelg's vision of Indigenous people as dependants, in which Hutt responded to Glenelg's orders to establish Indigenous reserves by blatantly refusing to do so. These political tug-of-wars confirm that colonial governance operated within a dialectic of imperial versus local imperative. They also reveal that the outcomes of these tug-of-wars-Western BNA's adoption of the pass system in 1885 and Western Australia's creation of reserves in 1905-tended to align with local rather than imperial imperatives.

Consider the moments at which Indigenous policy underwent change toward institutionalization. My research showed that in 19th century Western BNA, Indigenous reserve policy become considerably more coercive and institutionalized with the rise of the pass system after the 1885 North-West Uprising. The Canadian government considered the two causes of the uprising to be conspiratorial communication among Indigenous groups and food scarcity. The pass system addressed both issues by limiting communication and preventing farmers from abandoning their crops. In Western Australia, reserves were explicitly refused in favour of managing settler-Indigenous relations via employment, and the institutionalization of reserves was only undertaken in 1905 . The Commission on the Condition of the Natives had found a flaw in the rations system: Corrupt rations distributors had prevented those unable to work from accessing rations, leading to an increase in cattle theft. Reserves aimed to solve this problem by guaranteeing the distribution of rations to those unable to work and served local imperatives by ensuring safety from Indigenous cattle raids.

In each colony, the moment of institutionalization was predicated upon a threat to settler ways of life, whether that be Indigenous resistance in Western BNA or loss of Indigenous labour and increased cattle theft in Western Australia. Considering the political tug-of-wars between local governors and imperial administrators and the timing of institutionalization relative to moments of settler crises, the process of reserve formation cannot support a framework of overarching imperial imperative. However, the institutional reserves of the late 19th century did share that contradictory emphasis on civilizing Indigenous people, so let us consider this next.

\section{Definitions of Civilizing}

Of the three essential characteristics of Indigenous reserves established in section one -isolation, administration, and the mission to civilize - only two, isolation and administration, align with a framework of settler imperatives driving reserve policy, as they are both means of addressing the violence of resistance and the organization of labour. The concept of civilizing, however, does not align with this framework, since a civilizing mission is expensive and disruptive to peaceful

\footnotetext{
11 I say "desired" because Indigenous groups interacted with settler society for social and economic purposes whether it was policy or not, hence the need to create things like the pass system.
} 
settler-indigenous relations. If I am to argue that settler imperatives drove Indigenous reserve policy, as I do, then I must be able to explain why settlers would condone the expense and disruption of attempting to civilize Indigenous groups.

In Western BNA and Western Australia, civilizing on reserves was attempted through a combination of industrial education and law enforcement. Industrial education and law enforcement differed from the civilizing methods of early 19th-century Indigenous policies outlined in the 1837 Select Committee on Aborigines. The Committee emphasized that the goal of civilizing was to bring Indigenous peoples up to the level of Europeans, and that this was best carried out via education in all subjects (rather than just an industrial education). Furthermore, the Committee explicitly dictated that applying European-style laws to Indigenous groups would hamper the civilizing mission. Instead, colonies were to allow Indigenous groups to follow their own laws and continue traditional practices. Late 19th-century civilizing, on the other hand, refused to allow Indigenous groups to follow their own laws or participate in traditional activities, and provided only an industrial education. The imperial mission of the early 19th-century sought to improve Indigenous society regardless of whether indigenous society conformed to settler society, and the local mission of the late 19th-century sought to conform indigenous society to settler society regardless of whether Indigenous society improved. Therefore, while both early 19th-century imperial civilizing and late 19th-century local civilizing used the same language of civilization, they were doing two different things. Local settlers did not condone the expense and disruption of civilizing Indigenous groups, because they were not civilizing in the original meaning of the word. They were, more accurately, assimilating Indigenous groups, which was a departure from the civilizing mission of the early 19th-century.

Laidlaw argues that the British imperial imperative of liberal humanitarianism in regards to its civilizing mission did not exist in conflict with local imperatives, but rather that the imperial government abandoned its stance on civilizing around the 1850s. It is commonly accepted that humanitarianism faded throughout the 19th century as scientific conceptions of race developed, and Laidlaw's argument was developed within this context. She points to the British government's disinterest in challenging settler colonialism as a marker of Britain's complicity in settler colonialism via a "lack of imperial control" (Laidlaw, 2014, pp. 137-141). Her argument aligns with mine in results, as we both agree that local imperatives drove the institutionalization of reserves in the late 19th century. We disagree only in regards to the antagonistic relationship between the imperial and local governments. Laidlaw might argue that my study of reserve systems cannot reveal the subordination of imperial interests to local interests in the late 19th century because the humanitarianism that fueled the reversals of policy in the early 19th century no longer existed. However, I have never claimed that reserve policy hinged upon humanitarianism alone; from the beginning, I have acknowledged that both humanitarianism and imperial capitalism drove imperial interests. Consider the difference between Laidlaw's timeline of humanitarianism's decline and my timeline of reversals in reserve policy. Laidlaw argues that as of Lord Grey's tenure as Secretary of State for War and the Colonies (1846-1852), the imperial government had withdrawn from its civilizing mission, yet I have shown that the settler governments only began institutionalizing reserves in 1885 and 1894. Before these transitions, colonial reserves retained the imperial vision of civilizing, involving limited law enforcement, freedom to pursue traditional activities, and general education. These early reserves did not expend resources in attempts to enforce European laws or European agricultural practices on Indigenous groups, because doing so would go against the imperative of imperial capitalism. Therefore, whether liberal humanitarianism had faded by the 1850s or not, my study does reveal the subordination of imperial interests to local interests because local concerns subordinated concerns of imperial capitalism.

John Comaroff, professor of anthropology at Harvard, argues that "civilizing-colonialism" is concerned with spreading ideas of capitalism and liberalism, while "settler-colonialism" is concerned 
with establishing sovereign authority over foreign populations (1997, pp. 181-182). In Western BNA, the importance of the North-West Uprising in institutionalizing reserves suggests that the civilizing characteristics of reserves align with a settler-colonialist need for sovereignty rather than a civilizing-colonialist mission. Throughout the second half of the 19th century, Western BNA faced increasing pressure to establish sovereignty over the West to resist American encroachment. Canadian historian Desmond Morton argues that the United States could have substantiated a claim to sovereignty over Western BNA if the government had shown a lack of sovereignty via a breakdown in internal order, a movement for secession, or a failure to restrain hostile Indigenous groups $(1977$, p. 6). The North-West Uprising, therefore, represented a huge threat to sovereignty which was met with an assertion of power over the Indigenous population. Asserting power meant not only restricting Indigenous people's movement through the pass system, but also coercively suppressing their cultural difference from the settler society by quashing traditional activities and enforcing European laws.

In Western Australia, a parallel exists in the uncharacteristic adoption of institutionalized reserves in 1905. In section two, I found that the government's decision to abandon the earlier policy of allowing Indigenous people to live outside of reserves changed in the late 19th century, a result of the Indigenous people's declining ability to provide for themselves due to the decimation of kangaroo herds and food-production habitat. By centralizing the distribution of rations, government reserves served as a strategy to control the everyday lives of Indigenous people via controlling their access to food, and the institutionalization of reserves asserted settler sovereignty over the Indigenous population.

The civilizing mission of institutionalized reserves is therefore not at all contradictory to a locallydriven framework of colonial governance, because the definition of civilizing that institutionalized reserves operated upon was different from the definition of civilizing inherent in imperial Indigenous policy. The locally-driven framework was a reaction to Indigeneity as a threat to settler sovereignty, while imperial Indigenous policy was an extension of liberal humanitarianism's duty to spread enlightenment coupled with imperial capitalism's financial interests.

\section{Concluding Remarks}

This paper is a response to Laidlaw's call for transcolonial analyses, mentioned in the introduction, by seeking to understand, on a global scale, the colonial desire to isolate Indigenous people within reserves. As a response, it stands largely alone. There are few transcolonial histories written despite the many claims by historians that transcolonial analysis is necessary, and I set forth to write this paper with the intention to provide an example for historians who are new to this topic. Transcolonial analysis is not an easy task: It involves juggling temporal, geographical, and thematic structures in a way that is not traditional in historical narrative. No matter the findings of my research, I hope that historians will use this paper to think critically about how to do this sort of analysis.

My research found that, despite differences in local context, the institutionalized reserves of Western BNA and Western Australia were similar responses to settler concerns over sovereignty, including sovereignty over both land and culture, and that these local concerns over sovereignty subordinated and overrode imperial concerns over liberal humanitarianism and imperial capitalism. These findings are important for several reasons. In the ongoing movement towards reconciliation, it is common for settler-descendants to dismiss histories of colonialism as "something the British did a long time ago." Yet this paper illustrates how violent colonialism was a distinctly local/settler process which must be addressed by locals/settlers-descendants. Furthermore, this paper refutes the common perception that colonization was all about land, and therefore reconciliation only involves 
land claims. Reconciliation involves land, but it also requires settler-descendants to recognize the violence of the imposition of settler sovereignty, and to acknowledge the historical sovereignties of Indigenous nations. 
The Arbutus Review • $2017 \bullet$ Vol. 8, No. $1 \bullet$ http://dx.doi.org/10.18357/tar81201716801

\author{
References
}

\title{
Primary Sources
}

Bond Head, Sir F. (1839/1969). Sir Francis Bond Head to Lord Glenelg, 20 August 1836. In Irish University Press Series of British Parliamentary Papers: Colonies: Canada. Vol. 12. (pp. 350-352). (1969). Shannon, Ireland: Irish University Press.

Bond Head, Sir F. (1839/1969). Sir Francis Bond Head to Lord Glenelg, 20 November 1836. In Irish University Press Series of British Parliamentary Papers: Colonies: Canada. Vol. 12. (pp. 352-358). (1969). Shannon, Ireland: Irish University Press.

British Parliamentary Select Committee on Aborigines (British Settlements). (1837/1966) Report from the Select Committee on Aborigines (British Settlements). (1966) Cape Town, South Africa: C. Struik.

Canadian Department of Indian Affairs. (1886). Annual Report of the Department of Indian Affairs for the Year Ended 31st December, 1885. Ottawa, ON: MacLean, Roger \& Co. Retrieved from http://www.bac-lac.gc.ca/eng/discover/aboriginal-heritage/first-nations/indian-affairsannual-reports/Pages/item.aspx?IdNumber $=4050$

Canadian Department of Indian Affairs. (1887). Annual Report of the Department of Indian Affairs for the Year Ended 31st December, 1886. Ottawa, ON: MacLean, Roger \& Co. Retrieved from http://central.bac-lac.gc.ca/.item/?id=1886-IAAR-RAAI\&op=pdf\&app=indianaffairs

Glenelg, C. (1839/1970). Lord Glenelg to Governor Sir George Gipps, 31 January 1838. In Irish University Press series of British parliamentary papers: Colonies: Australia. Vol. 5. (pp. 374-391). (1970). Shannon, Ireland: Irish University Press.

Glenelg, C. (1839/1969). Lord Glenelg to Sir G. Arthur, 22 August 1838. In Irish University Press series of British parliamentary papers: Colonies: Canada. Vol. 10. (pp. 314-326). (1969). Shannon, Ireland: Irish University Press.

Hutt, J. (1844/1969). Governor Hutt to Marquis of Normandy, 11 February 1840. In Irish University Press series of British parliamentary papers: Colonies: Australia. Vol. 8. (pp. 371-373). (1969). Shannon, Ireland: Irish University Press.

Hutt, J. (1844/1969). Governor Hutt to Lord John Russell, 15 May 1841. In Irish University Press series of British parliamentary papers: Colonies: Australia. Vol. 8. (pp. 380-386). (1969). Shannon, Ireland: Irish University Press.

Indian Branch of the Department of the Secretary of State for the Provinces. (1871). Ottawa, ON: L.B. Taylor. Retrieved from http://www.bac-lac.gc.ca/eng/discover/aboriginal-heritage/firstnations/indian-affairs-annual-reports/Pages/item.aspx?IdNumber=141

Kempt, J. (1834/1969). Sir James Kempt to Sir George Murray, 20 May 1830. In Irish University Press series of British parliamentary papers: Anthropology: Aborigines. Vol. 3. (pp. 95-101). (1969). Shannon, Ireland: Irish University Press.

Middleton. (1885/2009). Middleton to Dewdney, 6 May 1885. In K. Smith. (2009). Liberalism, surveillance, and resistance: Indigenous communities in Western Canada, 1877-1927. (p. 63). (Edmonton, AB: Athabasca University Press.

Murray, G. (1834/1969). Sir George Murray to Sir James Kempt, 25 January 1830. In Irish University Press series of British parliamentary papers: Anthropology: Aborigines. Vol. 3. (pp. 87-89). (1969). Shannon, Ireland: Irish University Press.

Patterson, J. H. (1842, June 28). Proposed plan for the better treatment of the Aborigines of Australia Felix. Australasian Chronicle. (p. 4). Retrieved from http://trove.nla.gov.au/newspaper/ article/31736349? searchTerm $=$ \&searchLimits $=$-category $=$ Article|||-title $=48|| \mid$-decade $=184$ |||dateTo=1843-10-07|||1-month=6|||1-year=1842|||dateFrom=1839-08-02|||sortby=dateDesc. 
Royal Commission on the Condition of the Natives. (1905). Royal Commission on the Condition of the Natives Report. Perth, Australia: W.M. Alfred Watson. Retrieved from http://www.parliament.wa.gov.au/intranet/libpages.nsf/WebFiles/Royal+Commissions+-+ Report+of+the+Royal+Commission+on+the+condition+of+the+natives/\$FILE/Report+of +the+Royal+Commission+on+the+condition+of+the+natives.pdf

Symmons, C. (1841, January 9). Summary of the transactions of the past year, relative to the Aborigines. The Perth Gazette. (p. 3). Retrieved from http://trove.nla.gov.au/newspaper/ article/642592/1765

Vankoughnet, P. (1885/2009). Vankoughnet to Macdonald, 14 August 1885. In K. Smith. (2009). Liberalism, surveillance, and resistance: Indigenous communities in Western Canada, 18771927. (p. 64). Edmonton, AB: Athabasca University Press.

Western Australia Aborigines Department. (1905). Report for Financial Year Ending 30th June, 1905. Perth, Australia: A. Curtis. Retrieved from/http://aiatsis.gov.au/sites/default/files/docs /digitised_collections/remove/73455.pdf

Western Australia Houses of Parliament. (1905). An Act to Make Provision for the Better Protection and Care of the Aboriginal Inhabitants of Western Australia, 23rd December, 1905. Retrieved from http://aiatsis.gov.au/sites/default/files/docs/digitised_collections/remove/52790.pdf

\section{Secondary Sources}

Armitage, A. (1995). Comparing the policy of Aboriginal assimilation: Australia, Canada, and New Zealand. Vancouver, B.C.: University of British Columbia Press.

Barker, A., \& Battell Lowman, E. (2015). Settler Colonialism [Webpage]. Retrieved from http://globalsocialtheory.org/concepts/settler-colonialism

Barron, F. (1988). The Indian Pass System in the Canadian West, 1882-1935. Prairie Forum, 13(1), $25-42$.

Belich, J. (2009). Replenishing the earth: The settler revolution and the rise of the Anglo-world, 1783-1939. Oxford, U.K.: Oxford University Press.

Binnema, T., \& Hutchings, K. (2005) The emigrant and the noble savage: Sir Francis Bond Head's romantic approach to Aboriginal policy in Upper Canada, 1836-1838. Journal of Canadian Studies, 39(1), 110-31.

Carter, S. (1990). Lost harvests: Prairie Indian reserve farmers and government policy. Montreal, QC: McGill-Queen's University Press.

Carter, S., Hildebrandt, W., \& First Rider, D. (1996) The true spirit and original intent of treaty $\%$. Montreal, QC: McGill-Queen's University Press.

Churches, S. (2006). Put not your faith in princes (or courts)-agreements made from asymmetrical power bases: The story of a promise made to Western Australia's Aboriginal people. ANU E-Press. Retrieved from https://ssrn.com/abstract $=2364100$

Comaroff, J. (1997). Images of empire, contests of conscience: Models of colonial domination in South Africa. In F. Cooper \& L. Stoler (Eds.), Tensions of empire: Colonial cultures in a bourgeois world. Berkeley, CA: University of California Press.

Darwin, J. (2009). The empire project: The rise and fall of the British world-system, 1830-1970. Cambridge, U.K.: Cambridge University Press.

Laidlaw, Z. (2014). Imperial complicity: Indigenous dispossession in British history and historical writing. In C. Hall, N. Draper \& K. McClelland (Eds.), Emancipation and the remaking of the British imperial world. Manchester, U.K.: Manchester University Press.

Miller, J. (2009). Compact, contract, covenant: Aboriginal treaty-making in Canada. Toronto, ON: University of Toronto Press. 
Morton, D. (1977). Cavalry or police: Keeping the peace on two adjacent frontiers, 1870-1900. Journal of Canadian Studies, 12(2), 27-38.

Nettelbeck, A., \& Foster, R. (2012). Food and governance on the frontiers of colonial Australia and Canada's North West Territories. Aboriginal History 36, 21-41.

Satzewich, V. (1996). "Where's the beef?": Cattle killing, rations policy and First Nations "criminality" in Southern Alberta, 1892-1895. Journal of Historical Sociology 9(2), 188-212. 